\title{
Malign Akciğer Kanserli Hastalarda Üç-Port Video-Yardımlı Torakoskopik Cerrahi (VATS) ile Lobektomi Güvenle Uygulanabilir: Tek Merkezli Çalışma Sonuçları
}

\author{
Ezel Erşen $\odot$, Burcu Kılıç®, Hasan Volkan Kara®, Kamil Kaynak®
}

İstanbul Üniversitesi Cerrahpaşa Tıp Fakültesi, Göğüs Cerrahisi, İstanbul, Türkiye

\section{Ezel Erşen, Uzm. Dr.}

Burcu Kılıç, Uzm. Dr.

Hasan Volkan Kara, Uzm. Dr.

Kamil Kaynak, Prof. Dr.

\section{İletişim:}

Uzm. Dr. Ezel Erşen

İstanbul Üniversitesi Cerrahpaşa Tıp Fakültesi, Göğüs Cerrahisi, İstanbul, Türkiye

Tel: +902124143000

E-Posta:drezelersen@gmail.com
Gönderilme Tarihi : 13 0cak 2018

Revizyon Tarihi : 23 Mart 2018

Kabul Tarihi : 26 Mart 2018
ÖZET

Amaç: Bu çalışmada kliniğimizde 2010-2018 yılları arasında üç port VATS tekniği ile akciğer rezeksiyonu uygulanan malign akciğer tümörlü hastalarımızın sonuçlarını irdelemeyi amaçladık.

Hastalar ve yöntemler: Ağustos 2010-0cak 2018 tarihleri arasında toplam 46 hastaya (Erkek:37 hasta, Kadın:9 hasta) malign nedenler ile üç port VATS lobektomi uygulandı. Ortalama yaş 55.5 olarak saptandı (16-78 yaş arası). Hastaların ameliyat öncesi özellikleri (ek hastalık, komorbiditeler), kanama miktarı, ameliyat süreleri, yapılan rezeksiyon tipi, örneklenen lenf nodu sayıları, postoperatif takip özellikleri (drenaj miktarı, drenaj süresi, hastanede kalış süresi) , komplikasyonları, postoperatif ağrı skorları retrospektif olarak değerlendirildi.

Bulgular: Hastaların patolojik tanıs 29 hastada adenokarsinom, 10 hastada skuamöz hücreli karsinom ve 7 hastada diğer tümör tipleri olarak saptandı. Hastaların 21 tanesinde preoperatif komorbiditeler mevcuttu. Açı̆̆a dönme oranı \% 4.3 olarak saptandı. Operatif mortalite görülmedi. Ortalama operasyon süresi 169 dakika (75-285 dk.), hastanede kalış süresi ortalama 5.1 gün, ortalama dren kalış süresi 4.2 gün olarak hesaplandı. Peroperatif ve postoperatif drenaj miktarları sırası ile $219 \mathrm{ml}$ ve $679 \mathrm{ml}$ olarak ortaya konuldu. Komplikasyon oranı \%15.2 olarak saptandı (pnömoni 3 hasta \%6.5, Uzamış hava kaçağı 1 hasta \%2.1, aritmi 2 hasta $\% 4.3$ ve cilt altı amfizem 1 hasta \%2.1). Ameliyat sonrası 1 .gün görsel analog ağrı skalası değeri ise 2.8 değerindeydi. Ortalama çıkartılan lenf nodu örnekleri göz önüne alındığında ortalama çıartılan lenf nodu sayısı 17 olarak saptandı.

Sonuç: Malign akciğer kanserli hastalarda VATS lobektomi başarılla ve düşük morbidite ve tatmin edici postoperatif sonuçları ile güvenle tercih edilebilecek bir tekniktir.

Anahtar sözcükler: Akciğer kanseri, video-torakoskopi, lobektomi

TRIPORTAL VIDEO- ASSISTED THORACOSCOPIC (VATS) LOBECTOMY CAN BE PERFORMED SAFELY IN PATIENTS WITH MALIGNANT LUNG CANCER: RESULTS OF A SINGLE-CENTRE

\section{ABSTRACT}

Purpose: Our objective was to analyze the results of the patients with malignant lung tumor who underwent triportal VATS lung resection in our clinic in the $2010-2018$ period.

Patients and methods: Between August 2010 and January 2018, 46 patients with malignant tumors (37 male, 9 female) underwent triportal VATS lobectomy. Mean age of the patients was 55.5 (age range: 16-78). Patients' pre-operation features (additional diseases, comorbidities), amount of bleeding, operation duration, resection type, number of sampled lymph nodes, postoperative conditions (amount of drainage, duration of drainage, hospital stay), complications and postoperative pain scores were recorded.

Results: The pathological diagnosis was adenocarcinoma in 29 patients, squamous cell carcinoma in 10 patients and other tumor types in 7 patients. 21 patients had preoperative comorbidities. The conversion rate was $4.3 \%$. No operative mortality was observed. The average operation time was calculated as 169 minutes (range 75-285 minutes), while the average duration of hospital stay was 5.1 days and the average duration of drainage was 4.2 days. Perioperative and postoperative drainage was $219 \mathrm{~mL}$ and $679 \mathrm{~mL}$ respectively. Complication rate was 15.2 percent (pneumonia; $6.5 \%$, extended air leakage; $2.1 \%$, arrhythmia; $4.3 \%$ and subcutaneous emphysema; $2.1 \%$ ). The visual analogue pain scale value was 2.8 percent on the first post-operative day. Regarding the harvested lymph node samples, the average number of harvested lymph nodes was 17.

Conclusion: VATS lobectomy is a successful and reliable technique in patients with malignant lung cancer due to its low morbidity rates as well as satisfactory postoperative results.

Keywords: Lung cancer, video-assisted thoracoscopy, lobectomy 
A kciğer kanseri dünya genelinde kansere bağlı ölümlerin en sık nedenidir. Erken evre tümörlerde cerrahi rezeksiyon halen tedavide en uygun seçenektir $(1,2)$.

Son yıllarda gittikçe artan literatür verisi tarafından da desteklendiği şekilde video-yardımlı torakoskopik cerrahi (VATS) ile gerçekleştirilen anatomik akciğer rezeksiyonu ve lenf nodu diseksiyonu bu hasta popülasyonunda oldukça önemli bir alternatif oluşturmaktadır. Standart açık torakotomi yöntemi ile karşılaştııılığında VATS'ın daha az erken postoperatif ağrı, solunum parametrelerinde daha az bozulma, düşük postoperatif morbidite, kısa hastanede kalış süresi gibi avantajları olduğu bilinmektedir. Son yıllarda lobektomiyi tolere edemeyeceği düşünülen seçilmiş hastalarda sublobar akciğer rezeksiyonlarını öneren yazılar da mevcuttur $(3,4)$.

Bu çalışmada kliniğimizde 2010-2018 yılları arasında üç port VATS tekniği ile akciğer rezeksiyonu uygulanan malign akciğer tümörlü hastalarımızın sonuçlarını irdelemeyi amaçladık.

\section{Hastalar ve yöntemler}

Kliniğimizde 01 Ağustos 2010 - 1 Ocak 2018 tarihleri arasında toplam 55 hastaya (Erkek: 39 hasta, Kadın: 16 hasta) üç port VATS anatomik akciğer rezeksiyonu uygulandı. Bu hastaların 9 tanesine benign nedenler ile 46 tanesine (37 erkek, 9 kadın) ise malign nedenler ile rezeksiyon uygulandı. Malign nedenlerle rezeksiyon uygulanan grupta ortalama yaş 55.5 olarak saptandı (16-78 yaş arası). Hastaların demografik özellikleri ve tümör histolojik tipleri Tablo 1 ve Tablo 2'de izlenmektedir. Hastaların ameliyat öncesi özellikleri (ek hastalık, komorbiditeler), evreleri, kanama miktarı, ameliyat süreleri, tümör yerleşim yeri, yapılan rezeksiyon tipi, örneklenen lenf nodu sayıları, postoperatif takip özellikleri (drenaj miktarı, drenaj süresi, hastanede kalış süresi, ağrı skoru), komplikasyonları, mortalite oranları retrospektif olarak değerlendirildi. Hastaların postoperatif 1.gün ağrı değerlendirmesi için görsel analog skala (vizüel analog skala; VAS)kullanıldı ve ağrı miktarı 0-10 arası olarak değerlendirilerek veriler kayıt edildi. Tüm hastalara rutin ameliyat öncesi değerlendirme ve görüntüleme yöntemleri uygulandı ve uzak metastaz taraması yapıldı.

\section{Cerrahi prosedür}

Tüm hastalara tek akciğer ventilasyonunu sağlamak amacı ile genel anestezi altında çift lümenli tüple endobronşial entübasyon uygulandı. Hazırlıkları takiben hastaya lateral dekübit pozisyonu verildi ve cerrah hastanın anteriorunda kalacak şekilde pozisyon alındı. Kamera için 7. interkostal aralık orta aksiller hat seviyesinde yaklaşık $1.5 \mathrm{~cm}$ insizyon yapıldı. Sonrasında çalışma portu için 4 . interkostal aralık ön aksiller hatta, yaklaşık $4-5 \mathrm{~cm}$ ve skapula alt ucu posterior aksiller hat yaklaşık 6 . Interkostal hat seviyesinde $2 \mathrm{~cm}$ insizyonlar yapıldı. Diseksiyon esnasında uygun bakış açısını sağlamak ve kolay bir şekilde diseksiyon yapılabilmesi için her bir port deliği kamera, ekartasyon ve diseksiyon amacıyla kullanılabilir. Ön aksiller hattaki çalışma portu için endoskopik yara koruyucu plastik ekartör kullanıldı. Hastalara standart anatomik lobektomi ve hiler-mediastinal lenf nodu diseksiyonu uygulandı. İşlem esnasında diseksiyon için bipolar enerji cihazları, büyük vasküler yapılar ve bronş için lineer endovasküler stapler ve küçük vasküler yapılar için hemoklip kullanıldı. Rezeksiyonun tamamlanmasını takiben çıkarılacak akciğer dokusu endoskopik plastik torba yardımı ile vücut dışına alındı.

\section{Bulgular}

01 Nisan 2010- 01 Ocak 2018 tarihleri arasında kliniğimizde 46 hastaya (37 erkek; \%80.4, 9 kadın; \%19.5) malign akciğer tümörü tanısıyla üç port VATS anatomik akciğer rezeksiyonu uygulandı. Hastaların patolojik tanısı 29 hastada adenokarsinom, 10 hastada skuamöz hücreli karsinom ve 7 hastada diğer tümör tipleri olarak saptandı. Tümörlerin histolojik tipleri Tablo 2'de izlenmektedir. Lezyonların $\% 47.8^{\prime} i$ sağ tarafta yerleşirken, \%52.1'i de sol taraf yerleşimliydi. Hastaların 21 tanesinde preoperatif komorbiditeler mevcuttu (Tablo 1). Uygulanan rezeksiyon tipleri Tablo 3'te özetlenmiştir. İki hastada (1 hastada yapışıklık ve bir hastada kanama nedeniyle) torakotomiye dönülmüş olup açığa dönme oranı \%4.3 olarak saptandı. Operatif mortalite görülmedi. Bir hastada sağ üst lobektomiye ek olarak wedge rezeksiyon uygulanırken, bir vakada da sağ alt lobektomiye ek olarak üst lob büllektomi işlemi uygulandı. Dokuz hastada işlem tamamlayıcı lobektomi şeklinde yapılırken, tüm seride ortalama operasyon süresi 169 dakika (75-285 dk.) olarak saptandı. Hastanede kalış süresi ortalama 5.1 gün, ortalama dren kalış süresi 4.2 gün olarak hesapladı. Peroperatif ve postoperatif drenaj miktarlarına bakıldığında sırası ile bu değerler $219 \mathrm{ml}$ ve $679 \mathrm{~mL}$ olarak ortaya konuldu. Serimizde komplikasyon oranı \%15.2 olarak saptandı (pnömoni 3 hasta \%6.5, Uzamış hava kaçağı 1 hasta \%2.1, aritmi 2 hasta \%4.3 ve cilt altı amfizem 1 hasta \%2.1). Ameliyat sonrası 1.gün görsel analog ağrı skalası değeri ise 2.8 değerindeydi. Ortalama çıkartılan lenf nodu örnekleri göz önüne alındığında ortalama çıkartılan N1 lenf nodu sayısı 8.9 iken çıkartılan N2 lenf nodu sayısı 8.1 olarak saptandı (Tablo 3). Serimizde mortalite izlenmedi. 
Tablo 1. Hastaların demografik ve klinik özellikleri

$\begin{array}{ll}\begin{array}{l}\text { Cinsiyet } \\ \text { Kadın }\end{array} & 9 \\ \text { Erkek } & 37 \\ \text { Yaş } & 55.5 \text { (16-78 yaş) } \\ \begin{array}{l}\text { Ek hastalıklar (hasta) } \\ \text { Diyabet }\end{array} & 5 \\ \text { Hipertansiyon } & 16 \\ \text { Koroner arter hastalığı } & 8 \\ \text { KOAH } & 6 \\ \text { Böbrek hastalığı } & 1 \\ \text { Aritmi } & 1 \\ \text { Astım } & 1 \\ \text { Tbc } & 3\end{array}$

Tablo 2. Tümör histolojik tipleri

\begin{tabular}{lc} 
Tümör tipleri & Hasta sayısı \\
\hline Adenokarsinom & 29 \\
Skuamöz hücreli karsinom & 10 \\
Adenoskuamöz & 1 \\
Büyük hücreli & 2 \\
Tipik karsinoid & 1 \\
Mukoepidermoid & 1 \\
Pleomorfik & 1 \\
Müsinöz Adenokarsinom & 1
\end{tabular}

Tablo 3. VATS lobektomi yapılan hastalarda rezeksiyon tipi ve postoperatif takip değerleri

\begin{tabular}{lc} 
Başlık & Değer \\
\hline Uygulanan yöntem & 8 \\
Sol Üst lobektomi & 16 \\
Sol Alt lobektomi & 13 \\
Sağ Üst lobektomi & 3 \\
Sağ Orta lobektomi & 6 \\
Sağ Alt lobektomi & 169 \\
Ameliyat süresi (dk.) & 219 \\
Peroperatif kan kaybı (ml) & 679 \\
Postoperatif drenaj (ml) & 4.2 \\
Dren kalış (gün) & 5.1 \\
Hastanede kalış (gün) & 2.8 \\
Görsel ağrı skala skor ort. & 17 \\
Çıkartılan lenf nodu sayısı & \\
Ameliyat sonrası komplikasyonlar & 1 \\
Uzamış hava kaçağı & 3 \\
Pnömoni & 2 \\
Aritmi & 1 \\
Ciltaltı amfizem &
\end{tabular}

\section{Tartışma}

Son yirmi yılda video-yardımlı torakoskopik cerrahinin gelişmesi ile birlikte pek çok majör göğüs cerrahisi girişimi bu tip minimal invaziv metotlar kullanılarak yapılmaya başlanmıştır. Yapılan çalışmalar VATS ile yapılan ameliyatlar sonrasında daha az ağrı, daha düşük komplikasyon oranı ve daha kısa hastanede kalış süresi olduğunu göstermiştir $(5,6,7)$.

Aynı zamanda VATS cerrahi travmayı azaltmakla kalmaz aynı zamanda geleneksel açık cerrahi yöntemle eşdeğer onkolojik sonuçlar alınmasına da imkân sağlar (8).

Minimal invaziv girişimlerin doğasına uygun olarak postoperatif iyileşme süresini kısaltarak hastaneden kalış süresinin daha kısa olmasına neden olur. Bu sayede adjuvan tedavi ihtiyacı olan vakalarda hastaların tedaviyi daha erken alabilmesi de mümkün olur (9-12).

Genel olarak akciğer kanserinde VATS özellikle erken evre, lenf nodu tutulumu olmayan hastalar için önerilmektedir. Zhong ve arkadaşları özellikle evre 1a hastalarda segmentektominin de oldukça iyi sonuçlara neden olduğunu bildirmişlerdir. Bizim serimizde de rezeksiyon uygulanan 31 hasta erken evre akciğer kanserli hastalardı.(Evre 1A,1B). Yıllar içinde tekniğini kullanalar cerrahların tecrübesinin de gelişmesiyle birlikte daha ileri evrelerdeki tümörler için de uygulanabilir hale gelmiştir. Ancak son güncellemelerle birlikte $6 \mathrm{~cm}$ ve üzeri veya T3 tümörü olan hastalar VATS rezeksiyon için uygun görülmemektedir (13-17).

Literatürde VATS lobektomi sonrası komplikasyon oranları \%6 ile \%34.2 arasında değişen oranlarda bildirilmektedir. Whitson ve arkadaşlarının yaptığı bir çalışmada uzamış hava kaçağı $\% 56$, atrial fibrilasyon $\% 32$, masif plevral drenaj $\% 14$, pnömoni $\% 13$ ve miyokard infarktüsü $\% 10$ olarak bildirilmiştir (18). Bizim serimizde komplikasyon oranı \%15.2 olarak saptandı (pnömoni 3 hasta \%6.5, Uzamış hava kaçağı 1 hasta $\% 2.1$, aritmi 2 hasta $\% 4.3$ ve cilt altı amfizem 1 hasta \%2.1). Bir diğer çalışmada torakotomi ve VATS karşılaşıtırılmış ve uzamış hava kaçağı oranı \%1.5 ile daha kısa bulunmuştur: Aynı çalışmada hastanede kalış süresi de 4.5 gün bulunmuştur ki bu değer de torakotomi grubuna göre daha kısadır (19).

Bir başka çalışmada ise hastanede kalış süresi 5.3 gün olarak bildirilirken aynı çalışmada dren kalış süresi de 4 gün olarak bildirilmiştir (20). Biz de çalışmamızda hastanede kalış süresini ortalama 5.1 gün ve ortalama dren kalış süresi 4.2 gün olarak hesapladık. Bulgularımızın literatürle 
uyumlu olduğu görülmektedir. Sakura ve arkadaşlarının yaptığı bir çalışmada ortalama operasyon süresi 117.5 dakika olarak saptanmıştır. Bizim serimizde bu değer 169 dakikadır ancak ilk vakalarda öğrenme sürecinin başında olduğumuz göz önüne alındığında aradaki farkın çok anlamlı olmadığını düşünmekteyiz. Yine aynı çalışmada postoperatif drenaj miktarı da $987 \mathrm{ml}$ olarak bildirilmiştir ve bizim $679 \mathrm{ml}$ olan değerimizle benzerdir (19). Belgers ve arkadaşları ortalama ameliyat süresini 179 dakika ve peroperatif drenaj miktarı $444 \mathrm{ml}$ olarak bildirmişlerdir (6). Peroperatif kanama miktarı bizim çalışmamızda $219 \mathrm{ml}$ olarak saptandı.

Bir diğer önemli parametre olan açığa dönme oranı değişik serilerde \%2.5 ile \%6 arasında değişmektedir ki bu da bizim bildirdiğimiz \%4.3'lük açığa dönme oranı ile uyumlu görülmektedir.

VATS lobektomi sonrası ağrı takibi konusunda literatürde oldukça az veri mevcuttur ancak ortalama VAS skoru değerlerine bakıldığında 0.8 ile 6.2 arası değerler olduğu görülmektedir (21). Ancak bu çalışmalar arasında sadece üç port lobektomi yapılan vakalar değil aynı zamanda

\section{Kaynaklar}

1. Siegel RL, Miller KD, Jemal A. Cancer statistics, 2015. CA Cancer J Clin 2015;65:5-29. [CrossRef]

2. Howington JA, Blum MG, Chang AC, Balekian AA, Murthy SC. Treatment of stage I and II non-small cell lung cancer: diagnosis and management of lung cancer, 3rd ed: American College of Chest Physicians evidence-based clinical practice guidelines. Chest 2013;143:e278S-313S. [CrossRef]

3. Yan TD, Black D, Bannon PG, McCaughan BC. Systematic review and meta-analysis of randomized and nonrandomized trials on safety and efficacy of video-assisted thoracic surgery lobectomy for earlystage nonsmall- cell lung cancer. J Clin Oncol 2009;27:2553-62. [CrossRef]

4. Cao C, Chandrakumar D, Gupta S, Yan TD, Tian DH. Could less be more?-A systematic review and meta-analysis of sublobar resections versus lobectomy for non-small cell lung cancer according to patient selection. Lung Cancer 2015;89:121-32. [CrossRef]

5. Ismail M, Helmig M, Swierzy M, Neudecker J, Badakhshi H, GonzalezRivas D, Rückert JC. Uniportal VATS. the first German experience. J Thorac Dis 2014;6:S650-5. [CrossRef]

6. Sakuraba M, Miyamoto $\mathrm{H}$, Oh S, Shiomi K, Sonobe S, Takahashi N et al. Video-assisted thoracoscopic lobectomy vs. conventional lobectomy via open thoracotomy in patients with clinical stage IA nonsmall cell lung carcinoma. Interact Cardiovasc Thorac Surg 2007;6:614-7. [CrossRef]

7. Sawada S, Komori E, Yamashita M, Nakata M, Nishimura R, Teramoto $\mathrm{N}$, et al. Comparison in prognosis after VATS lobectomy and open lobectomy for stage I lung cancer: retrospective analysis focused on a histological subgroup. Surg Endosc 2007;21:1607-11. [CrossRef]

8. Park BJ. Is surgical morbidity decreased with minimally invasive lobectomy? Cancer J 2011;17:18-22. [CrossRef] pnömotoraks cerrahisi ve akciğerin hacim küçültücü cerrahisi uygulanan vakalar da mevcuttur. Bununla birlikte bizim bildirdiğimiz $2.8^{\prime}$ lik ortalama ağrı skoru değerinin yine literatürle uyumlu bir değer olduğu görülmektedir (13). Tabi ki bu parametre açısından yeni ve prospektif randomize çalışmalara ihtiyaç vardır.

Son olarak çıkarılan lenf nodu sayılarına baktığımızda bizim serimizde bu oranı ortalama 17 lenf nodu olarak saptadık (N1 lenf nodu sayısı 8.9- N2 lenf nodu sayısı 8.1). Literatürde bu parametre için 126-25.4 arası değerler bildirilmektedir (22).

\section{Sonuç}

Son yıllardaki gelişimi sayesinde VATS ile rezeksiyon torakotomi için kabul edilebilir bir alternatif olarak kullanılmaya başlanmıştır. Özellikle de yüksek riskli olarak kabul edilen hastalarda VATS ile uygulanan rezeksiyonlar son yıllarda neredeyse altın standart haline gelmiştir. Çalışmamızın sonuçlarından da görüldüğü şekilde akciğer kanserli hastalarda bu yöntem başarıyla ve düşük morbidite ve tatmin edici postoperatif sonuçları ile güvenle tercih edilebilecek bir tekniktir.

9. Gonzalez D, Delgado M, Paradela M, Fernandez R. Uni-incisional video-assisted thoracoscopic left lower lobectomy in a patient with an incomplete fissure. Innovations (Phila) 2011;6:45-7. [CrossRef]

10. Rocco G, Internullo E, Cassivi SD, Raemdonck DV, Ferguson MK. The variability of practice in minimally invasive thoracic surgery for pulmonary resections. Thorac Surg Clin 2008;18:235-47. [CrossRef]

11. Zhang Z, Zhang Y, Feng $H$, Yao Z, Teng J, Wei D, Liu D. Is video-assisted thoracic surgery lobectomy better than thoracotomy for early-stage non-small-cell lung cancer? A systematic review and metaanalysis. Eur J Cardiothorac Surg 2013;44:407-14. [CrossRef]

12. Teh E, Abah U, Church D, Saka W, Talbot D, Belcher E, Black E. What is the extent of the advantage of video-assisted thoracoscopic surgical resection over thoracotomy in terms of delivery of adjuvant chemotherapy following non-small-cell lung cancer resection? Interact Cardiovasc Thorac Surg 2014;19:656-60.

13. Dziedzic D, Orlowski T. The Role of VATS in Lung Cancer Surgery: Current Status and Prospects for Development. Minim Invasive Surg 2015;2015:938430. [CrossRef]

14. Congregado M, Merchan RJ, Gallardo G, Ayarra J, Loscertales J.Videoassisted thoracic surgery (VATS) lobectomy:13 Years' experience. Surg Endosc 2008;22:1852-7. [CrossRef]

15. Zhong C, Fang W, Mao T, Yao F, Chen W, Hu D. Comparison of thoracoscopic segmentectomy and thoracoscopic lobectomy for small-sized stage IA lung cancer. Ann Thorac Surg 2012;94:362-7. [CrossRef]

16. Herth JFF, Ernst A, Eberhardt R, Vilmann P, Dienemann H, Krasnik M. Endobronchial ultrasound-guided transbronchial needle aspiration of lymph nodes in the radiologically normal mediastinum. Eur Resp J 2006;28:910-4. [CrossRef] 
17. Burfeind WR, D'Amico TA. Thoracoscopic lobectomy. Oper Tec Thorac Cardiovasc Surg 2004;9:98-114. Erişim: https://www.optechtcs. com/article/S1522-2942(04)00030-3/pdf

18. Whitson BA, Groth SS, Duval SJ, Swanson SJ, Maddaus MA. Surgery for early-stage non-small cell lung cancer: a systematic review of the video-assisted thoracoscopic surgery versus thoracotomy approaches to lobectomy. Ann Thorac Surg 2008;86:2008-18. [CrossRef]

19. Sakuraba M, Miyamoto H, Oh S, Shiomi K, Sonobe S, Takahashi $\mathrm{N}$. Video-assisted thoracoscopic lobectomy vs. conventional lobectomy via open thoracotomy in patients with clinical stage IA non-small cell lung carcinoma. Interact Cardiovasc Thorac Surg 2007;6:614-7. [CrossRef]
20. Demmy TL, Curtis JJ. Minimally invasive lobectomy directed toward frail and high-risk patients: a case-control study. Ann Thorac Surg 1999;68:194-200. [CrossRef]

21. Belgers EHJ, Siebenga J, Bosch AM, van Haren EHJ, Bollen ECM. Complete video-assisted thoracoscopic surgery lobectomy and its learning curve. A single center study introducing the technique in The Netherlands. Interact Cardiovasc Thorac Surg 2010;10:176-80. [CrossRef]

22. Harris CG, James RS, Tian DH, Yan TD, Doyle MP, Gonzalez-Rivas D, Cao C. Systematic review and meta-analysis of uniportal versus multiportal video-assisted thoracoscopic lobectomy for lung cancer. Ann Cardiothorac Surg 2016;5:76-84. [CrossRef] 